\title{
Barbarian resistance and rebel alliances: social movements and Empire(1)
}

(May 2000, published in Rethinking Marxism, fall/winter 2001)

For Colin Barker

Introduction: reading Empire

Empire is a curious and challenging book. Although it sets out to be a latter-day Communist Manifesto, it lacks the concrete aesthetic, the urgent pace of argument, and the practical cutting edge of the latter. There are sound material reasons for this, some of which its authors would doubtless acknowledge: it is not, after all, the product of the needs and temperature of a radical organisation, written in the midst of a great revolutionary wave.

What Empire is not, however, is made up for in some ways by what it is. A closer analogy than with the Manifesto would probably be with the German Ideology. Like that work, Empire offers a "a general theoretical framework and a toolbox of concepts" (p.xvi), still some way detached from the actual use of those tools, and a sustained exposure to a particular way of thought which - just maybe - can help particular kinds of militant to see themselves and their situation in new ways, ways they can then practice in concrete movements. An even closer analogy would be with contemporary socialist science fiction. Caught in this same period where the assured languages and strategies of the mid-century have finally broken down, while new senses of potentiality are stirring on the fringes of what can be articulated, authors like MacLeod (1995 etc.), Miéville (2000), Byrne (1999) or Robinson (1993 etc.) show us successful moments of popular revolt, placed in settings which illuminate the present without being allegories and driven by forms of agency which bear a similarly metaphoric relationship to reality.

The richly allusive nature of the book makes this a stronger way to read what Empire has to say on social movements than a formal critique of an analysis of movements which it lacks, in that sense of a neat organisation of propositions. It is not a book which is easy to grasp on first reading; like Starhawk or Le Guin(2), it demands rereading ("front to back, back to front, in pieces, in a hopscotch pattern, or through correspondences" (p. xvi)) to enter into its mental world and find new possibilities there.

To keep going in the present, an important resource may be to recognise that we do not know as much as we thought we did: like the barbarian priest or the rebel volunteer, we understand our local struggles but find it hard to grasp their insertion within - and challenge to - Empire. In our own provinciality, of campaigns and 
jobs, gatherings and books, what do we gain - and what do we not find - in Hardt and Negri's alternate world?

\section{Form and irony: the multitude in struggle}

Any artistic tradition embodies - in a sense, is - a particular understanding of how the world works and what we are doing in it. In the Icelandic family sagas - or in Thomas Hardy's best poems characters are deeply constrained by the forms of traditional practices. They may make limited choices at the outset, but must then follow their implications through to what is usually a grimly ironic outcome.

In conventional academic writing on social movements, matters are somewhat different(3). The characters - who are most commonly social movement organizers - are constrained, not by the past, but by the logic of their environment, a logic which is usually naturalised, as if the institutional contexts of this or that core capitalist polity in the post-68 period were a microcosm of the world(4).

Even when, as in more recent writing, their action comes to be seen as a skilled performance(5), they are not permitted to overturn the background sets - and the audience are not allowed to storm the stage. In this deeply bourgeois view of reality, agency is the property of individuals dwarfed by market, state and culture - and the dramatic action centres on the liminal moments of "unconventional political action", thereby eliding the everyday agency that produces and reproduces structure.

Hardt and Negri's world-building rules (to borrow a term from science fiction writing practices(6)) go beyond this, and do not stop at the more "transparent" sense of (collective) structure as the product of (individual) agency: a transparency which stresses above all collusion and consent, since the way things are is clearly in some sense a product of what we do - but what we do, we do not do freely. Instead, they tell us, popular struggles (co-) constitute the social order: "We need to identify a theoretical schema that puts the subjectivity of the social movements of the proletariat at center stage in the processes of globalization and the constitution of global order" (p. 235). Generalising the 1859 Preface's discussion of the tension between the forces and relations of production (Cohen 1978) to the whole of social life, it transpires that it is at each stage of capitalist development the creative power of "the multitude", directly producing social life, that come to press against the forms of capitalist accumulation. It is precisely this creativity and this pressure, however, that capitalism makes use of in its own self-transformation: without popular struggles, capitalists would have neither the impetus nor the capacity for this leap into the unknown: "The proletariat actually invents the social and productive forms that capital will be forced to adopt in the future." (p. 268) 
One implication of this understanding is that attention should be directed, not so much towards the most articulated forms of popular struggles - organisations, direct action, or even the production of theory - as to the everyday activities of ordinary people. This suggests an aesthetic of the soap opera more than of the court epic, implying an attention to domestic rows and workplace routines rather than to battles and genealogies: "Here is where the primary site of struggle seems to emerge, on the terrain of the production and regulation of subjectivity." (p. 321)

\section{Toolboxes and soap operas}

What is strangely lacking, though, is the "toolbox of concepts" needed to engage with these everyday activities, a toolbox which might be furnished by the tradition of materialist cultural studies: The long revolution (Williams 1965), The making of the English working class (Thompson 1963), Resistance through rituals (Hall and Jefferson 1991), for example, or in some ways Postmodernism and cultural studies (McRobbie 1994).

Of particular interest - not least because it offers the possibility of a direct connection between these practices and the production of articulated political theory - is the discussion of tacit knowledge produced by subordinate groups in their struggles, an argument usefully stated by Wainwright (1994) with reference to moments of struggle in particular.

Moving back to the 20s and 30s, Gramsci's analysis of hegemony rested in part on precisely this theme of the "two consciousnesses" of ordinary people, that inherent in their productive and cooperative action and that embodied in official language and institutions (Gramsci 1991: 13; cf. Cox 1998). This analysis enables not only an immanent relationship between revolutionary theory and popular practice - the one as the development of the other - but holds out the possibility of saying something more specific about the revolutionary potential of popular action, to which I now turn.

\section{Emotion, or Where's the buzz in reading that?}

The presentation of a particular kind of world-view in any artistic tradition depends on a determinate relationship to a particular repertoire of emotional disciplines, even when these are challenged, poorly performed or toyed with. To pick up a collection of Chinese hermit poems - or a copy of a campaign newsletter - is to pick up a certain set of expectations, even when those expectations are different in different audiences.

What kinds of emotional terrain does a book like Empire operate on? The normal expectations of a book like this might include that lowgrade boredom associated with work, or a more politicised alternation between the spark of recognition and agreement on the one hand and 
the sensation of tension and dissent on the other. Beyond these, at least two kinds of special emotional depth are possible. One, a recognition of real intellectual breakthroughs in the rediscovery and redescription of social reality (as in the German Ideology), is hardly to be found here, partly as a result of its recursively allusive style in which the world is never seen anew, as further literary twists are turned on existing modes of discourse.

What is present, and makes the exercise worthwhile, is a sense of the immanence of revolutionary potential. Bubbling behind the postmodern architecture of contemporary capitalism and forms of rule is the immensely creative life of Hardt and Negri's multitude, capable at any moment of throwing the whole edifice into turmoil: "The creative forces of the multitude that sustain Empire are also capable of autonomously constructing a counter-Empire, an alternative political organization of global flows and exchanges." (p. xv) Here Hardt and Negri rejoin a different strand in contemporary social movement writing, which has been concerned to stress the extent to which popular creativity produces an immensely powerful surplus. For Katsifiacas (1987), following Marcuse, an "eros effect" is produced in world-revolutionary moments such as 1848 or 1968 . The conservative Maffesoli (1996) instead sacralizes modern sociality as in effect beyond mere rational categories. Empire's alternative is better, because more historical:

"at this point in development class struggle acts without limit on the organisation of power. Having achieved the global level, capitalist development is faced directly with the multitude, without mediation [?] the situation of struggle is completely open." (pp. 236 - 7)

As capitalist expansion has reached its limits in terms of global extension and the "death of nature", it has found its new frontier internally, in the colonisation (Habermas 1987), commodification (Offe 1984) and production of everyday life: "The universality of human creativity, the synthesis of freedom, desire, and living labor, is what takes place in the non-place of the postmodern relations of production." (p. 210) Under these conditions, forms of communicative and affective labour take centre stage, in a process of autopoietic "generation":

"Labor is productive excess with respect to the existing order and the rules of its reproduction. This productive excess is at once the result of a collective force of emancipation and the substance of the new social virtuality of labor's productive and liberatory capacities." (p. 357)

The politics of the everyday 
For our authors, the "biopolitics" which results is not the defence of the uncontaminated lifeworld any more than it is a politics of locality: "Empire can be effectively contested only on its own level of generality and by pushing the processes that it offers past their present limitations." (p. 206) As good modernists, the subjects of this biopolitics are constituted on this terrain which they themselves produce. In a parallel to Marx's more "structuralist" writings, the possibility of revolutionary transformation is immanent to Empire. Yet this is not, apparently, because of the socialization of capital so much as because of the commodification of feelings, style, bodies, intelligence and symbols - which then offers the possibility of reappropriation:

"Exchanges and communication dominated by capital are integrated into its logic, and only a radical act of resistance can recapture the productive sense of the new mobility and hybridity of subjects and realize their liberation. This rupture, and only this rupture, brings us to the ontological terrain of the multitude and to the terrain on which circulation and hybridisation are biopolitical." (pp. 363 - 4; my italics)

A concrete example of this potential can perhaps be imagined - to keep with the science fiction theme - in the new Star Wars movie. A mid-century Marxism, before the return of the word "alienation", might have stressed simply the immense material and technical capacities represented by such a project, from the scale of its distribution and merchandising to the feats of computer-generate imagery involved (cf. Bouzereau and Duncan 1999). The implication of Hardt and Negri's analysis might be that the true emancipatory potential is not only technical but also that of the social production of symbols and affect. This potential is concretised, perhaps, by the ready availability of detailed information about the production, personalities and economics of the project. If, as Giddens (1990) says, we are only experts in one area, yet we can imagine being experts and creators in any area( 7$)$.

The risks in this style of thought - which parallels Luk 'optimistic teleology (p. 395) - should be obvious by now. Even if Empire's generative power is historical in a way that Maffesoli's fetishisation of the everyday is not, what secures it against the "cultural populism" McGuigan (1994) warns against? What if ordinary people already feel free - and are happy with Star Wars as it is? After all, as the discussion of "rupture" quoted above continues, "Biopolitical circulation focuses on and celebrates the substantial determinations of the activities of production, self-valorization and freedom." (p. 364) What if this does not appear as a far-off goal, but as the nature of the (commodified) everyday?

Hardt and Negri offer two related ways of dealing with this issue. One is that generation is in a sense organic, while the processes that 
brought it into being are (already?) coming to seem external, artificial, fetters or vampires (p. 359; cf. Carver 1998), so that a conflict between "generation" and "corruption" is in some senses inevitable. The other, which follows from this, is that what is key is potentiality and capacity: "By the virtual we understand the set of powers to act (being, loving, transforming, creating) that reside in the multitude" (p. 357).

It is less clear, though, if Empire in fact thrives on crisis and breakdown (p. 385) - or, as Berman (1983) and Jameson (1990) put it, the essence of capitalism is change and creative destruction - why the conflict between the two should be a problem for it. We are told:

"Generation is there, before all else, as basis and motor of production and reproduction [.?] We have thus reached a limit of the virtuality of the real subsumption of productive society under capital - but precisely on this limit the possibility of generation and the collective force of desire are revealed in all their power." (p. 389) But has capitalism in fact reached its limits, as Hardt and Negri - and Arrighi's rather different (1994) analysis - allow us to hope?

A key question here is that of incorporation, and not only in the cultural realm. Empire itself describes (rightly) the extent to which the networks of social life characteristic of the new social formation are the products of the movements of the 60s and 70s. The question then is perhaps not so much whether and how long the global service class analysed by Sklair (1995) or Lash and Urry (1987) is willing to continue attempting to exercise hegemony - something which, as Singh (1999) reminds us, is always a taking account of pressures from below. It is rather how and when movements from below become willing and able to move from incorporation to revolution: "The refusal of exploitation - or really resistance, sabotage, insubordination, rebellion and revolution - constitutes the motor force of the reality we live, and at the same time is its living opposition." (pp. 208 - 9; my italics)

This is where Hardt and Negri's decision to abolish the dialectic becomes a weakness: they can only resolve the contrast (as it must now be called) between revolutionary potential and dismal reality, both fuelled by the same source, with a sense that things are about to blow: "The only event that we are still awaiting is the construction, or rather the insurgence, of a powerful organization" (p. 411). But what if this doesn't happen?(8) Here perhaps a more determinate analysis of popular culture, and its internal tensions, might have something to offer.

\section{Plots: characters, actions, resolutions}

At this point in our reading, something can be asked about the nature of the people who appear as characters within a particular kind of writing. Are they embodiments of ideals, are they split between public norms and private selves, are they fragmented or elusive? What kinds of relation does the form in question allow between character and 
action - driven by a god, working out the logics of their personality, responding superficially to random cues? And what kinds of resolution are possible - a fated end, a marriage, a departure? Hardt and Negri's understanding of their characters seems ambiguous, which may be a strength in political theory as in art if it captures something of the contradictory real that cannot (yet?) be captured in rational words or practices. On the one hand, the multitude is not a People. It is so far from being this that its struggles are mutually incommunicable, despite objective similarities: "the figure of an international cycle of struggles based on the communication and translation of the common desires of labor in revolt seems no longer to exist" (p. 54). And yet - precisely because of this, it seems - each such struggle strikes at the heart of Empire: "each struggle, though firmly rooted in local conditions, leaps immediately to the global level and attacks the imperial constitution in its generality." (p. 56)

I have my doubts about both aspects of this. One concrete example can be offered by the struggle in Chiapas, mentioned in Empire. It is clearly not incommunicable, however, even if Marcosismo and Zapatismo are allied rather than identical (Ortiz-Perez 2000). In fact, as Rudé (1980) observed, it is of the nature of peasant struggles that their success depends on alliance with other, less radically particularist, strata, who can enable crucial forms of internal and external communication. Hardt and Negri write:

"(potential) revolutionaries in other parts of the world did not hear of the events in Beijing, Nablus, Los Angeles, Chiapas, Paris, or Seoul and immediately recognize them as their own struggles. Furthermore, these struggles not only fail to communicate to other contexts but also lack even a local communication" (p. 54).

Yet, as Olesen has observed, "Solidarity groups, NGOs, and individuals tied to the Zapatista struggle in different degrees are found all over the world today, tied together in a complex transnational network facilitated by modern communication technologies, and using the EZLN as a symbolic center." (2000: 5)(9) In Ireland, activists in fields as different as anarchist politics, women's community education and the underground music scene have been mobilised in different ways by the events in Chiapas, and seem to have no difficulty in "immediately recogniz[ing] them as their own struggle"(10).

The Zapatista-sponsored Encuentros, moreover, seem on anecdotal evidence to have been an important step in the global coming-together of movements that ultimately made the Seattle protests possible(11). If such struggles do not constitute a traditionalist "unity-in-diversity" or a new International in the making, they are nevertheless part of a process of communication across important social distances. On the other side, is Chiapas necessarily a threat to the heart of Empire? Hellman (1999) has made some cogent arguments against 
this view, arguments which might be strengthened by noting that RAND research for the US Army (Ronfeldt et al. 1998) uses virtually the same language of postmodern enthusiasm about Chiapas as do the promoters of the view that an event like Chiapas is not simply an important struggle but a magic moment(12). The latter enthusiasm, perhaps, says more about the projection of our desires onto social movements elsewhere when we feel unable to make connections where we are than it does about the movements of Central America - let alone their capacity to overthrow patriarchal capitalism en bloc(13).

\section{Process and praxis}

What seems lacking, in this incommunicable-but-revolutionary analysis of contemporary movements, is much of a sense of process of the building of communication and the need to struggle for the meaning of a movement (Barker 1996). That these are particularly problematic at present does not overcome the basic point that a revolutionary movement consists of people learning to communicate and cooperate in the social production of something new - a point which Hardt and Negri recognise at other times in the analysis:

"We need a force capable of not only organizing the destructive capacities of the multitude but also constituting through the desires of the multitude an alternative. The counter-Empire must also be a new global vision, a new way of living in the world." (p. 214)

The lack of any clear sense of the process involved in getting that far is the more surprising since their correct insistence that the proletariat is not reducible to the industrial working class (p. 402) should allow them to overcome the "contemplative" relation between "intellectuals" and "workers", in a sense that movements do not just happen, they are done by people like us:

"it becomes ever more difficult to maintain distinctions among productive, reproductive, and unproductive labor. Labor - material or immaterial, intellectual or corporeal produces and reproduces social life, and in the process is exploited by capital." (p. 402)

Such a recognition - along with the stress on biopolitics - would also allow for a rethinking of class / gender issues along the lines suggested by Jaggar (1983) or, in a somewhat different key, Lynch and McLaughlin (1995). Yet the words "socialist feminism" are buried in a footnote (no.17, pp. 422 - 423), and - despite the valuable insistence on the experience of the 1960s and 1970s - there is little or no overt reflection on the implications of the fragmentation and recomposition of social movements dating from that period for contemporary 
revolutionary movements. Perhaps the concept of incommunicability renders an Abrechnung superfluous?

The problem of the separation of vision and process is a general one in Empire: although it sets out to provide revolutionary theory, it is very coy as to its methodology, so that the authors wind up appearing as separate from the struggles to which they offer theory as any urban intellectual might to a peasant rebellion. The authorial voice here is anything other than postmodern: it is omniscient and detached. The contrast with the Communist Manifesto is revealing here. Empire is strong on the analysis of the development of contemporary capitalism and the hidden possibilities of human creativity. It makes a stab at offering a list of key demands (p. $400 \mathrm{ff}$.) What lies logically between these two - the discussion of "telos" and "posse" (pp. 403 - 11) - is deeply abstract, more the Marx of the 1844 manuscripts at the point of enthusing about the possibilities of labour than the Marx of four years later(14).

Recall the Manifesto's arguments as to the relationship between the developing forces of production, the deepening interaction of the proletariat, the growth in class consciousness and the progress of class struggles; or its analysis of the relationship between communist theory and practice and proletarian struggles. It is not that these arguments, in Marx and Engels, are definitive - far from it - it is rather than Hardt and Negri seem to deny the need for any theory of how the new class struggles might be expected to develop, or of how their analysis is related to the developing self-consciousness of contemporary movements. On this level, Empire has neither a theory of social movements nor a theory for social movements.

The clerks and the simple

The point is not that Hardt and Negri are not communist militants, or that theirs is not a revolutionary theory. It is that it is void of any determinate sense of the relationship between theory and practice, with contradictory results. To leave the future open to the creativity of the multitude, as Hardt and Negri do (p. 206), would make sense if theirs was a theory which saw itself as immanent to proletarian struggles(15). Yet although their goal is the creation of organisation and counterpower, there is a "hands-off" tone to their understanding of struggles which makes this demand for organisation seem deeply abstract - and removed from the real problems of organisation in the present time:

"We await only the maturation of the political development of the posse. We do not have any models to offer for this event. Only the multitude through its practical experimentation will offer the models and determine when and how the possible becomes real." (p. 411) 
Here the intellectuals and their analysis of the present, there the multitude and their practice of the future. On the other hand, and within the turn of a page from this kind of writing, we find the following:
"Militancy today is a positive, constructive, and innovative activity. This is the form in which we and all those who revolt against the role of capital recognize ourselves as militants today [?.] This militancy makes resistance into counterpower and makes rebellion into a project of love." (p. 413)

Here there is a sense that intellectual activity may be in some ways both organic to ordinary people's struggles and have an active role to play within them. How can this tension be reconciled? Hardt and Negri identify two approaches in their work:
"the first is critical and deconstructive, aiming to subvert the hegemonic languages and social structures and thereby reveal an alternative ontological basis that resides in the creative and productive practices of the multitude; the second is constructive and ethico-political, seeking to lead the processes of the production of subjectivity toward the construction of an effective social, political alternative, a new constituent power." (p. 47)

In these terms, they are far more successful in the former than the latter. In essence, they are faced with the same problem as Arrighi, Hopkins and Wallerstein (1989) in trying to move from an analysis of "the system" to an analysis of the forces that oppose it. Like Lukács (1971), they resolve this tension with a surprisingly abstract and enthusiastic response to agency, lacking any determinate analysis of the complexities of movement politics.

Perhaps the nearest thing to a resolution of this tension comes on page 350: "We would be anarchists if we were not to speak [?] from the standpoint of a materiality constituted in the networks of productive cooperation". As Thompson argued long ago, however, the issue is not simply one of a "whole way of life", but rather that of a "whole way of struggle" (Hall 1989: 61).

There is a kind of neo-populism in Empire which - having first destroyed the "naturalness" of the everyday through capitalist intervention in the production of social networks, affect, etc. - then treats the latter as already external and devoid of any hegemonic power, for all the world as if all that was needed was for the intellectuals to buzz off and leave ordinary folk to do what they know best. But the power of the service class runs deeper than that, as Gramsci knew.

This point should not be pushed too far. The relationship between organic and traditional intellectual activity is no longer where Gramsci 
found it in the 20s. And the issues of political organisation on the left at the start of the 21 st century are manifestly deeply problematic: "the traditional forms of resistance [?] have begun to lose their power. Once again a new type of resistance has to be invented." (p. 308) Under these conditions, the double stress on the agency of ordinary people and on the scope for lightness and joy in the life of the militant (p. 413) are deeply liberatory themes. But are militants not also in some important ways part of the multitude - and do they not ultimately seek to combine lightness and agency, together with other people? And where do their ideas come from?

Hardt and Negri's ideal militant is the "organization-lite" Wobbly: "The perpetual movement of the Wobblies was indeed an immanent pilgrimage, creating a new society in the shell of the old, without establishing fixed and stable structures of rule." (p. 207) Part of the difficulty in contemporary capitalism, however, is that activist practices do not always find it easy to combine the mobility of the Wobbly agitator with their ability to strike roots locally, as Lichterman's excellent (1996) study of the differences between libertarian and community-based forms of environmental activism shows(16). The separation between intellectuals and activists written into the rationalist structure of Empire and taken away in its political rhetoric is a key element in this problematic, and one which Hardt and Negri do not manage to resolve.

\section{Conclusion}

In Tacitus' history of the Roman conquest of Britain, a Pictish chieftain he names as Calgacus is given a set-piece speech before the final battle in which he criticises the systemic power of the Empire; the speech is remembered today for the cutting phrase "desertam faciunt, pacem appellant" - "they make a desert and they call it peace". The irony, of course, is that the speech is a rhetorical piece of Noble Savagery on Tacitus' part, into which he places a criticism of the constitution of a system which he - but not the Pictish clansmen knew from the inside(17). In some ways, revolutionaries today are in a situation more like the actual chieftain (whatever he called himself) than Tacitus' imagined one:

"It is midnight in a night of specters. Both the new reign of Empire and the new immaterial and cooperative creativity of the multitude move in shadows, and nothing manages to illuminate our destiny ahead." (p. 386)

Our local struggles are available to us, and we can grasp intuitively something of the workings of the system we struggle against. Yet as large-scale revolutionary organisation has declined in the 70s and $80 \mathrm{~s}$, and new ways of practicing politics have developed in the $90 \mathrm{~s}$ (Jordan and Lent 1999), it has become harder to find conceptual tools 
to work with the new reality, because of the as yet amorphous and inarticulate nature of the new struggles.

Hence the weaknesses and strengths of socialist science fiction, and also those of Empire. The strengths lie in a cast of mind that can grasp something of the conflict under the surface, the depth beneath the "end of history", and the potential beneath the real. The weaknesses lie in our ability to specify these in useful terms - which is closely connected to weaknesses in actual cooperation and communication(18). Under these circumstances, contradictory thought may be our only alternative to no thought at all.

At the end of the day, the value of Empire for social movements lies more in its imaginative abilities than in its concrete specifications for action. There was a time when revolutionaries read history to learn mental flexibility and depth of imagination so as to be able to go beyond the immediately given. As flatter and more static forms of social theory come to predominate, it is more important than ever to resist the collapse into the present-day and find positive resources for moving beyond it. This Hardt and Negri do, in abundance.

\section{References}

References by page number only are to Michael Hardt and Antonio Negri, Empire. Cambridge, Massachusetts: Harvard University Press, 2000

Anderson, Benedict

1991 Imagined communities: reflections on the origin and spread of nationalism. London: Verso (2nd edition)

Arrighi, Giovanni

1994 The long twentieth century: money, power and the origins of our times. London: Verso

Arrighi, Giovanni; Hopkins, Terence; Wallerstein, Immanuel

1989 Antisystemic movements. London: Verso

Barker, Colin

1996 "What is to be done? Contrasting activists' visions in community protest." 25 - 44 in Colin Barker and Paul Kennedy (eds.), To make

another world: studies in protest and collective action. Aldershot:

Avebury

Berman, Marshall

1983 All that is solid melts into air: the experience of modernity.

London: Verso

Bouzereau, Laurent and Duncan, Jody

1999 Star Wars: the making of Episode I. London: Ebury

Byrne, Eugene

1999 ThiGMOO. London: Earthlight

Carver, Terrell

1998 The postmodern Marx. Manchester: Manchester University Press 
Charlton, John

2000 "Talking Seattle!" International Socialism 86: 3 - 18

Cohen, Gerry

1978 I Oxford: Clarendon

Cox, Laurence

1998 "Gramsci, movements and method: the politics of activist

research." In Colin Barker and Mike Tyldesey (eds.), Alternative futures

and popular protest IV (vol. I). Manchester: Manchester Metropolitan

University

1999a "Power, politics and everyday life: the local rationalities of social movement milieux." 44 - 64 in Paul Bagguley and Jeff Hearn (eds.), Transforming politics: power and resistance. London: Macmillan / British Sociological Association

1999b "Structure, routine and transformation: movements from below at the end of the twentieth century." In Colin Barker and Mike

Tyldesley (eds.), Fifth international conference on alternative futures

and popular protest (vol. I). Manchester: Manchester Metropolitan

University

2000 Building counter culture: the radical praxis of social movement

milieux. Unpublished PhD thesis, Department of Sociology, Trinity

College Dublin.

della Porta, Donatella and Diani, Mario

1999 Social movements: an introduction. Oxford: Blackwell

Foweraker, Joe

1995 Theorizing social movements. London: Pluto

Giddens, Anthony

1990 The consequences of modernity. Cambridge: Polity

Gramsci, Antonio

1991 Il materialismo storico e la filosofia di Benedetto Croce. Roma:

Riuniti

Habermas, Jürgen

1987 The theory of communicative action (vol. 2). Lifeworld and system:

a critique of functionalist reason. Cambridge: Polity

Hall, Stuart

1989 "Politics and letters." 45 - 66 in Terry Eagleton (ed.), Raymond

Williams: critical perspectives. Cambridge: Polity

Hall, Stuart and Jefferson, Tony (eds.)

1991 (orig. 1975) Resistance through rituals: youth subcultures in post-

war Britain. London: HarperCollins

Hellman, Judith

1999 "Real and virtual Chiapas: magic realism and the left." 161 - 186

in Leo Panitch and Colin Leys (eds.), Socialist Register 2000.

Rendlesham: Merlin

Jacoby, Russell

1981 Dialectic of defeat: contours of western Marxism. Cambridge:

Cambridge University Press

Jaggar, Alison

1983 Feminist politics and human nature. Brighton: Harvester 
Jameson, Frederic

1990 Postmodernism, or the cultural logic of late capitalism. Durham,

NC: Duke University Press

Jasper, James

1997 The art of moral protest: culture, biography and creativity in social movements. Chicago: University of Chicago Press

Jordan, Tim and Lent, Adam (eds.)

1999 Storming the millennium: the new politics of change. London:

Lawrence and Wishart

Katsiaficas, George

1987 The imagination of the new left: a global analysis of 1968.

Boston: South End

Lash, Scott and Urry, John

1987 The end of organized capitalism. Cambridge: Polity

Le Guin, Ursula

1974 The dispossessed: an ambiguous utopia. London: Gollancz

1980 Malafrena. London: Gollancz

1989 The language of the night: essays on feminism and science fiction.

London: Women's Press (2nd edition)

Lewis, Tammy

2000 "Transnational conservation movement organizations: shaping

the protected area systems of less developed countries." Mobilization, vol. 5, no. 1: $101-122$

Lichterman, Paul

1996 The search for political community: American activists reinventing commitment. Cambridge: Cambridge University Press

Lukács, Györgi

1971 History and class consciousness: studies in Marxist dialectics.

London: Merlin

Lynch, Kathleen and McLaughlin, Eithne

1995 "Caring labour and love labour." 250 - 292 in Patrick Clancy et

al. (eds.), Irish society: sociological perspectives. Dublin: Institute of

Public Administration / Sociological Association of Ireland

McCarney, Joseph

1990 Social theory and the crisis of Marxism. London: Verso

McGuigan, Jim

1994 "Trajectories of cultural populism." 547 - 559 in John Storey

(eds.), Cultural theory and popular culture: a reader. Hemel

Hempstead: Harvester.

MacLeod, Ken

1995 The star fraction. London: Legend

McRobbie, Angela

1994 Postmodernism and popular culture. London: Routledge

Maffesoli, Michel

1996 The time of the tribes: the decline of individualism in mass

society. London: Sage

Miéville, China

2000 Perdido Street station. London: Macmillan 
Offe, Claus 1984 Contradictions of the welfare state. London:

Hutchinson

Olesen, Thomas

2000 "Mapping the invisible continent: theoretical and analytical

reflections on transnational networks." Paper to UC San Diego

conference "Critical citizenship: the role of non-governmental

organisations in civil society"

Ortiz-Perez, Luisa

2000 "Marcos and the EZLN guerrilla in Chiapas: spaces of political

change provided by revolutionary discourses, 1994 - 1996." In Colin

Barker and Mike Tyldesley, Sixth international conference on

alternative futures and popular protest (vol. II). Manchester:

Manchester Metropolitan University

Robinson, Kim

1993 Red Mars. London: HarperCollins

Ronfeldt, John et al.,

1998 The Zapatista social netwar in Mexico. Santa Monica: RAND

Rudé, George

1980 Ideology and popular protest. London: Lawrence and Wishart

Schmidt, Stanley

1995 Aliens and alien societies. Cincinnati: Writer's Digest

Singh, Hari

1999 "Popular protest in princely states and India's post-colonial

unity: colonial mode of historiography and subaltern studies." In Colin

Barker and Mike Tyldesley (eds.), Fifth international conference on

alternative futures and popular protest (vol. II). Manchester:

Manchester Metropolitan University

Sklair, Leslie

1995 Sociology of the global system (2nd edition). London: Prentice

Hall

Starhawk

1997a The fifth sacred thing. London: Thorsons

1997b Walking to Mercury. London: Thorsons

Tarrow, Sidney

1998 Power in movement: social movements and contentious politics.

Cambridge: Cambridge University Press (2nd edition)

Thompson, Edward

1963 The making of the English working class. London: Gollancz

Wainwright, Hilary

1994 Arguments for a new left: answering the free-market right.

Oxford: Blackwell

Wignaraja, Ponna (ed.)

1993 New social movements in the South: empowering the people.

London: Zed

Williams, Raymond

1965 The long revolution. Harmondsworth: Penguin 
1 This piece was written in May 2000. Subsequent events in Porto Alegre, Mexico City and Genova have marked significant steps forward in movement development. The issues raised here - of what to do have become more rather than less important. See http://www.iol.ie/ mazzoldi/toolsforchange/revolution.html for a related, and more recent, analysis. Back

2 Both, paradoxically or not, authors with a more determinate sense of collective agency (Starhawk 1997a, Le Guin 1974) and a stronger historical sense (Le Guin 1980, Starhawk 1997b) than the socialist men just listed. Back

3 See della Porta and Diani (1999) for a recent overview. Back 4 This critique, and the general perspective on social movements adopted in the rest of this essay, is developed in Cox (2000).Back 5 See Jasper (1997) for an extended argument along these lines. Back 6 A conventional approach is represented by Schmidt (1995). For a radical version, see Le Guin (1989). Back

7 This argument as to the immanence of revolutionary potential is only one possible reconstruction of a discussion which remains implicit at key points in Empire's argument. The theme of immanence, however, is entirely explicit, as are the attempts discussed subsequently to ground its potential for realisation. Back 8 Jacoby's (1981) Dialectic of defeat charts in some detail what comes next in intellectual terms after the falsification of linear expectations that the immanent is also imminent. Back

9 See also Tarrow (1998) or Lewis (2000) on contemporary forms of global or transnational social movement organization - and, in a different key, Anderson's (1990) comments on "long-distance nationalism", a notably effective form of politics over the last 10 years or so. Back

10 Negri is of course himself the "symbolic center" of another such process of transnational solidarity. The campaign in support of his courageous stand on behalf of other political exiles has clearly struck a chord of recognition with activists and ex-activists in many places (the toni-negri e-mail list, for example, attracts postings in at least four languages: http://groups.yahoo.com/group/toninegri). Back 11 For an oral history of the latter, see Charlton 2000. Back

12 This suggests the need for strong scepticism about the view that there is something inherently radical in this kind of analysis. Back 13 See Wignaraja (1993) and Foweraker (1995) for some useful points of reference on majority world movements. Back

14 The historical parallel is more than polemic; my own sense would be that a general optimism about the potential for transformative action combined with the lack of any clear picture of how this might come about characterises many activists (and would-be activists) today, as it is likely to in the period prior to a new revolutionary upsurge. Back

15 See McCarney (1990) for a relevant argument as to the nature of Marxist theory. Back 
16 I have explored some of the tensions involved from the side of practices in Cox (1999a). Back

17 The Picts, however, were not a purely literary construction: their victory at Mons Graupius was sufficiently decisive that the Romans abandoned the project of conquering northern Scotland permanently. Back

18 See Cox (1999b) for a discussion of these latter points. Back

Back to "Talkin' 'bout a revolution" index 